\title{
Analisis Dampak Akreditasi dalam Peningkatan Mutu Pendidikan di Paud X Kota Pangkalpinang
}

\author{
Jurdis Rizky Kumala*, Arif Hakim \\ Prodi Pendidikan Guru PAUD, Fakultas Tarbiyah dan Keguruan, \\ Universitas Islam Bandung, Indonesia. \\ *jurdisrizkykum@gmail.com, arifhakim.spsupi@gmail.com
}

\begin{abstract}
This thesis research wants to describe and examine the impact of accreditation in improving the quality of education at the Tamasha Valaq PAUD institution, Pangkalpinang city. This thesis uses qualitative research with case study research methods. Data were collected in three ways, namely (1) Interview, (2) Documentation, (3) Observation. Furthermore, the data that has been collected is analyzed with the flow of (1) data reduction, (2) data display, (3) conclusion. The results of the research found are as follows (1) seen from the eight national quality standards of early childhood education, $90 \%$ have met the existing standards. This is reflected in every implementation of the eight educational qualities. Although there is one standard that is not in accordance with the existing educational quality standards, the institution continues to strive to improve educational services so that the quality of education at the institution can still be achieved. (2) accreditation has a positive impact on the institution. This can be seen from the physical evidence displayed by the institution, starting from adequate and complete facilities and infrastructure, improving teacher performance, and increasing trust from the community and government. The institution continues to strive to increase the productivity of its institution in order to achieve the expected quality of education. The institution involves all elements of the school to continue to maintain and improve the quality of education so that the next accreditation will remain in a proper condition from all aspects of the quality of education.
\end{abstract}

Keywords: accreditation, quality of education, early childhood.

\begin{abstract}
Abstrak. Penelitian skripsi ini ingin mendeskripsikan dan mengkaji dampak dari akreditasi dalam peningkatan mutu pendidikan di lembaga PAUD X kota Pangkalpinang. Skripsi ini menggunakan penelitian kualitatif dengan metode penelitian studi kasus. Data dikumpulkan melalui tiga cara yaitu (1) Wawancara, (2) Dokumentasi, (3) Observasi. Selanjutnya data yang telah terkumpul dianalisis dengan alur (1) Reduksi data, (2) Display data, (3) Kesimpulan. Hasil penelitian yang ditemukan adalah sebagai berikut (1) dilihat dari delapan standar nasional mutu pendidikan anak usia dini $90 \%$ telah memenuhi standar yang ada. Hal ini tergambar didalam setiap pelaksanan delapan mutu pendidikan tersebut. Walaupun terdapat satu standar yang kurang sesuai dengan standar mutu pendidikan yang ada, namun lembaga terus berupaya untuk meningkatkan pelayanan pendidikan agar tetap tercapainya mutu pendidikan di lembaga tersebut.(2) akreditasi memberikan dampak yang positif bagi lembaga. Hal ini dilihat secara bukti fisik yang ditampilkan oleh lembaga mulai dari sarana dan prasarana yang memadai dan lengkap, peningkatan kinerja guru, dan kepercayaan dari masyarakat dan pemerintah yang semakin tinggi. Lembaga terus berupaya untuk meningkatkan produktivitas lembaganya agar tercapai mutu pendidikan yang diharapkan. Lembaga melibatkan seluruh unsur sekolah untuk terus mempertahankan dan meningkatkan mutu pendidikan agar pada akreditasi berikutnya tetap dalam keadaan layak dari segala segi mutu pendidikan.
\end{abstract}

Kata Kunci: akreditasi, mutu pendidikan, pendidikan anak usia dini. 


\section{A. Pendahuluan}

Pendidikan Anak Usia Dini (PAUD) merupakan awal dari pendidikan yang lebih tinggi dan menjadi kunci dalam memperbaiki kualitas bangsa. Oleh sebab itu, pemerintah telah mencanangkan PAUD sebagai salah satu prioritas pembangunan pendidikan di Indonesia. Lembaga PAUD menjadi suatu lembaga pendidikan yang saat ini dianjurkan untuk diikuti oleh anak-anak usia dini di Indonesia khususnya 5-6 tahun, sebagai bentuk persiapan menuju ke jenjang Sekolah Dasar. Untuk mencapai tujuan dari Pendidikan Anak Usia Dini diperlukan sebuah lembaga yang layak memiliki mutu serta layanan pendidikan yang baik. Maka dari itu diperlukan sebuah penilaian mutu penyelenggaraan pendidikan oleh suatu lembaga independen yang dinamakan Badan Akreditasi Nasional Pendidikan Anak Usia Dini (PAUD) dan Pendidikan Non Formal (PNF) yang telah dilakukan sejak tahun 2008. Pemerintah telah melakukan berbagai macam upaya untuk meningkatkan kualitas pendidikan dengan menetapkan standar kualitas pendidikan melalui Undang-undang RI Nomor 20 tahun 2003 tentang Sistem Pendidikan Nasional. Standar yang telah ditetapkan untuk meningkatkan kualitas pendidikan Indonesia tersebut salah satunya adalah akreditasi. Akreditasi di sekolah adalah suatu proses untuk mengukur kelayakan sekolah. Menurut Mendiknas No. 087/U/202 dalam peraturannya tentang pedoman akreditasi sekolah menjelaskan bahwa tujuan akreditas adalah untuk memperoleh gambaran kinerja dan tingkat kelayakan suatu sekolah dalam menyelenggarakan pendidikan yang diwujudkan dalam predikat atau status sekolah yang diharapkan dapat meningkatkan mutu pendidikan. Akreditasi merupakan suatu tahapan penilaian yang dilakukan oleh lembaga tertentu yang bertugas menilai tentang keberadaan, kelengkapan dan implementasi dokumen/program lembaga yang dilaksanakan sesuai dengan kriteria standar yang telah ditetapkan dalam peraturan perundang-undangan.

Menurut Ratih Permatas (Hermiyanty, Wandira Ayu Bertin, 2017), dalam penelitiannya menjelaskan bahwa dengan predikat akreditas lembaga PAUD mendapatkan kepercayaan dari para masyarakat untuk menitipkan anak-anak mereka.

Untuk melihat dampak akreditasi dalam peningkatan mutu PAUD, maka peneliti tertarik untuk melakukan penelitian tentang dampak akreditasi peningkatan mutu pendidikan lembaga pendidikan anak usia dini yang terdapat di kota Pangkalpinang, tepatnya di TK Tamasha Valaq yang telah terakreditasi A. Peneliti ingin mengetahui setelah terakreditasi A dan prestasi yang telah dicapai, apakah memiliki dampak yang signifikan terhadap perkembangan dan peningkatan mutu pendidikan serta kualitas lembaganya. Sehingga dari penelitian ini dapat mendeskripsikan dan mengkaji bagaimana dampak dari akreditasi di lembaga tersebut.

\section{B. Metodologi Penelitian}

Pada penelitian kali ini desain penelitian yang digunakan adalah penelitian kualitatif. Penelitian kualitatif bertujuan untuk membuat suatu gambaran kompleks, meneliti kata-kata, laporan terinci dari pandangan responden dan melakukan studi pada situasi yang alami. Menurut (Sugiyono, 2019) penelitian kualitatif merupakan suatu metode penelitian dengan filsafat positivisme menjadi landasannya. Penelitian kualitatif bertujuan untuk mendeskripsikan suatu fenomena atau kejadian yang terjadi sesuai dengan fakta yang ada di lapangan yang nantinya akan menghasilkan data deskriptif berupa tulisan. Metode yang digunakan dalam penelitian ini yaitu studi kasus. Penelitian studi kasus merupakan metode penelitian yang memfokuskan untuk mengamati fenomena kontemporer (objek yang akan diteliti sedang berlangsung atau telah berlangsung tetapi masih berdampak dan memiliki pengaruh yang luas, kuat atau khusus pada saat penelitian dilakukan ) dengan menggunakan sumber sebagai data (Muliawan, 2016). Dalam penelitian ini teknik pengumpulan data yang digunakan adalah wawancara, dokumentasi dan observasi. Sedangkan teknik analisis data dalam penelitian ini adalah reduksi, penyajian data dan penarikan kesimpulan.

\section{Hasil Penelitian dan Pembahasan}

Berdasarkan hasil penelitian dan pembahasan tentang analisis dampak akreditasi dalam peningkatan mutu pendidikan lembaga di PAUD X secara keseluruhan telah memenuhi standar mutu pendidikan PAUD yang telah ditetapkan dalam Peraturan Menteri Pendidikan dan 
Kebudayaan No.137 Tahun 2014 tentang standar nasional pendidikan anak usia dini. Hal ini dibuktikan dengan lembaga yang telah melaksanakan dan memenuhi instrumen penilaian akreditasi, sehingga tercapainya nilai A. Kelengkapan dokumen dan administasi, sarana dan prasarana di PAUD X dapat dikatakan sudah lengkap. Hal ini tidak terlepas dari adanya kesiapan lembaga saat menghadapi akreditasi. Seluruh dokumen dan administrasi serta keperluan lainnya yang diminta sesuai instrument penilaian akreditasi yaitu yang mencakup delapan standar mutu pendidikan telah dipersiapkan sebelumnya.

Lembaga selalu berusaha dalam meningkatkan produktifitas progam dan kegiatan sekolah dengan melengkapi dokumen dan administrasi. Selain itu, sarana dan prasarana yang ada juga sudah sangat memadai. Usaha dalam peningkatan kinerja guru juga telah dilakukan oleh lembaga dengan memberikan dukungan dan arahan, serta memperhatikan kesejahteraan guru agar tetap semangat dalam menjalankan tugasnya. Lembaga juga mendapatkan kepercayaan yang tinggi dari masyarakat dan pemerintah setempat.

Akreditasi sekolah ternyata memberikan dampak yang positif terhadap upaya lembaga dalam peningkatan mutu pendidikan di PAUD X. Hal ini tergambar dalam pelaksanaan depalan mutu standar nasional pendidikan yang dijalankan di lembaga tersebut. Pada bagian standar yang belum memenuhi standar nasional PAUD lembaga terus mengupayakan untuk memenuhi standar tersebut.

Lembaga selalu mengevaluasi dengan seluruh unsur sekolah untuk mempertahankan yang sudah baik dan memenuhi standar mutu pendidikan, juga meningkatkannya agar pada akreditasi di tahun berikutnya lembaga masih dalam keadaan yang layak dan baik dari segala segi mutu pendidikan.

\section{Kesimpulan}

Berdasarkan hasil penelitian yang telah dilaksanakan tentang analisis dampak akreditasi dalam peningkatan mutu pendidikan lembaga di PAUD X adalah sebagai berikut :

1. Dilihat dari pelaksanaan delapan mutu standar pendidikan PAUD yang mengacu pada peraturan menteri pendidikan nomor 137 tahun 2014 tentang standar nasional PAUD yang didalamnya terdapat delapan standar mutu pendidikan PAUD yaitu STPPA, standar isi, standar proses, standar pendidik dan tenaga kependidikan, standar sarana dan prasarana, standar pengelolaan, standar pembiayaan dan standar penilaian PAUD X 90\% telah memenuhi. Hal ini tergambar didalam setiap pelaksanan delapan mutu pendidikan tersebut. Walaupun terdapat satu standar yang kurang sesuai dengan standar mutu pendidikan yang ada, namun lembaga terus berupaya untuk meningkatkan pelayanan pendidikan agar tetap tercapainya mutu pendidikan di lembaga tersebut.

2. Dampak akreditasi terhadap peningkatan mutu pendidikan lembaga dapat dilihat secara bukti fisik yang ditampilkan oleh lembaga mulai dari sarana dan prasarana yang memadai dan lengkap, peningkatan kinerja guru, dan kepercayaan dari masyarakat dan pemerintah yang semakin tinggi. Hal ini dapat dikatakan bahwa lembaga terus berupaya untuk meningkatkan produktivitas lembaganya agar tercapai mutu pendidikan yang diharapkan. Lembaga melibatkan seluruh unsur sekolah untuk terus mempertahankan dan meningkatkan mutu pendidikan agar pada akreditasi berikutnya tetap dalam keadaan layak dari segala segi mutu pendidikan. Dengan akreditasi A yang diperoleh, sekolah semakin berupaya untuk memenuhi standar nasional pendidikan yang telah ditentukan dan semakin meningkatkan pelayanan pendidikannya. Hal ini menunjukkan bahw akreditasi sangat penting adanya karena erat kaitannya dengan mutu pendidikan sekolah yang akan menjadi nilai terhadap sekolah tersebut. Akreditasi juga berdampak positif dimata para stakeholder dan masyarakat sebagai pelanggan di lembaga pendidikan.

\section{Acknowledge}

Penulis ucapkan terima kasih kepada :

1. Yang terhormat Ibu Hj. Dr. Nan Rahminawati, Dra., M.Pd. selaku dosen pembimbing I yang telah membimbing dengan memberikan yang terbaik dalam penyelesaian penelitian ini. Terima kasih untuk selalu sabar dan selalu meluangkan waktu dalam membimbing 
penelitian ini.

2. Yang terhormat Bapak Arif Hakim, M.Pd., selaku dosen pembimbing II yang telah sabar membimbing penulis dalam penyusunan penelitian ini. Terima kasih atas segala waktu yang telah diluangkan dalam penyelesaian penelitian ini.

\section{Daftar Pustaka}

[1] A Hakim (2018). Tingkat Kepuasan Orangtua terhadap Layanan Pendidikan Lembaga PAUD. Golden Age: Jurnal Pendidikan Anak Usia Dini.

[2] Badan Akreditasi Nasional. (2019). Kebijakan Dan Mekanisme Akreditasi Paud Dan Pnf Tahun 2019.

[3] Fadhli, M. (2017). Manajemen Peningkatan Mutu Pendidikan. Tadbir: Jurnal Studi Manajemen Pendidikan.

[4] Fithri, R., \& Anggraini, W. (2018). Peningkatan Mutu Sekolah TK Melalui Akreditasi SeKecamatan Pucuk Rantau Kabupaten Kuantan Singingi. PAUD Lectura: Jurnal Pendidikan Anak Usia Dini.

[5] Hermiyanty, Wandira Ayu Bertin, D. S. (2017). Dampak Akreditasi Terhadap Mutu PAUD di KB Al Amin Desa Sumber Bendo Kecamatan Bantur Kabupaten Malang. Journal of Chemical Information and Modeling, 8(9), 1-58.

[6] Kemendikbud. (2014). Peraturan Menteri Pendidikan dan kebudayaan Republik Indonesia Nomor 57 Tahun 2014 tentang Kurikulum Sekolah Dasar/Madrasah Ibtidaiyah. Education.

[7] Permendikbud 13 Tahun_2018., Kementrian Pendidikan dan Kebudayaan Republik Indonesia (2018).

[8] Muliawan, J. U. (2016). Metode Penelitian Pendidikan dengan Studi Kasus.

[9] Pemerintah RI. (2005). Peraturan Pemerintah No. 19 Tahun 2005. Standar Nasional Pendidikan.

[10] Pemetaan Tingkat Pencapaian Mutu Program Pendidikan Anak Usia Dini (Paud) di Propinsi DIY. (2007). Jurnal Pendidikan Luar Sekolah.

[11] Poerwadarminta. (2005). Kamus Umum Bahasa Indonesia. Jakarta: Balai Pustaka. Muhibbin Syah.

[12] Sudibyo, B. (2009). Sistem Penjaminan Mutu Pendidikan. Permendiknas.

[13] Sugiyono. (2016). Metode Penelitian Pendidikan Pendekatan Kuantitatif, Kualitatif, dan R\&D. ALFABETA.

[14] Pendidikan Di Indonesia Pasca Amandemen Undang Undang Dasar Tahun 1945. Jurnal Pendidikan Nusantara Indonesia.

[15] Yanto, M., \& Fathurrochman, I. (2019).Manajemen Kebijakan Kepala Madrasah Dalam Meningkatkan Mutu Pendidikan.

[16] Umar, N. (2015) Paradigma Baru Sistem 